\title{
Fiscal Policy of Economic Development: Comparative Characteristics of Ukraine and Poland
}

\author{
Olha Sliusarchuk ${ }^{1 *}$, Ruslan Lavrov², Vasyl Kuybida ${ }^{3}$, \\ Maksym Slatvinskyi ${ }^{4}$, Andrii Zelenskyi ${ }^{5}$ \\ 'Taras Shevchenko National University of Kyiv, Ukraine \\ ${ }^{2}$ Faculty of Economics and Management, European University, Ukraine \\ ${ }^{3}$ National Academy for Public Administration, Ukraine. \\ ${ }^{4}$ Pavlo Tychyna Uman State Pedagogical University, Ukraine. \\ ${ }^{5}$ Podillya State Agrarian and Engineering University, Ukraine. \\ E-mail: 'slyusarchuk.olha@gmail.com, 2lavrus2017@gmail.com, 3kuybida58@gmail.com, \\ 4siat.maks@gmail.com, 5zelenskiy2306@gmail.com
}

${ }^{*}$ Corresponding Author

\section{JEL Classification:}

E62

F63

$\mathrm{H} 21$

Received: 06 June 2021

Revised: 11 July 2021

Accepted: 14 August 2021

\begin{abstract}
In order to achieve the purpose outlined, this research uses the following methods: analysis and synthesis; economic and statistical analysis and comparison; economic and mathematical; generalization. The result shows that Poland's fiscal policy aims at developing economic infrastructure and building an economic model of the state based on the manufacture of products with a high share of value-added. However, the fiscal policy of Ukraine does not have significant effects on economic development due to the use of such instruments as public debt and capital expenditures. However, the external debt dependence of the state is relatively high. Nevertheless, it proves that the fiscal policy of Ukraine does not increase the level of economic complexity and development of the processing industry through the implementation of tax benefits. It proposes to increase the efficiency of tax authorities in Ukraine in terms of combating the shadow economy, boost the share of capital expenditures and raise the level of conversion of public debt into economic growth.
\end{abstract}

Keywords:

total factor productivity, human capital, technological transfer, CPEC, special economic zones

\section{How to Cite:}

Sliusarchuk, O., Lavrov, R., Kuybida, V., Slatvinskyi, M., \& Zelenskyi, A. (2021). Fiscal Policy of Economic Development: Comparative Characteristics of Ukraine and Poland. Etikonomi, 20(2), 275 - 296. https://doi.org/10.15408/etk. v20i2.22013. 


\section{Introduction}

Fiscal policy, as a policy of managing state revenues and expenditures in influencing aggregate demand and economic development, has always been the subject of scientific discussions in world economic thought. Particular attention is paid to the fiscal policy under the conditions of the economic crisis. After all, thanks to the operative decisions of the government in the field of mobilization of state budget revenues and structuring of its expenditures towards anti-crisis purposes, it is often possible to achieve macroeconomic stability.

At the same time, one of the research areas is the study of the role of fiscal policy in ensuring economic development, analyzing the strategies for using specific fiscal instruments. Considering Ukraine's economic development level and permanent political and economic crises, studying the best experience in implementing the fiscal policy of economic development is a highly urgent objective. The experience of those neighboring countries, with which Ukraine has a common historical past and today are at a higher level of development, deserves special attention. Consequently, a comparative analysis of the fiscal policy of Poland and Ukraine is intended to answer the question concerning the role of fiscal policy in economic development, the effectiveness of its instruments, and strategic orientation.

This study aims to compare Poland and Ukraine's economic development levels to determine the baseline conditions for the direction of fiscal policy of these countries. The purpose of the research is to do a comparative analysis of the fiscal policy of Poland and Ukraine to determine the advantages and disadvantages of its impact on economic development and outline the vectors of adaptation of best experience for the national economy. Besides that, this research also investigates the impact of the state budget deficit, expenditures and revenues, and debt policy on the GDP in Poland and Ukraine. Moreover, this research also analyses the effectiveness of preferential taxation of enterprises in Poland and Ukraine. In terms of their compliance with the structure of economic development and development objectives of the state.

The investigation of the background on the use of fiscal policy towards stimulating economic growth has had a long-term history. However, Keynes took a fundamental approach towards this issue, forasmuch as he substantiated the effectiveness of budget financing of aggregate demand. The basic postulates of the Keynesian theory were practice by US President F. Roosevelt during his anti-crisis policy (Renshaw, 1999). The Keynesian theory was continued in the works of Lerner, in which the theory of the so-called "functional finances" was substantiated (Niggle, 2010; Hart, 2013).

Later, in the scientific literature, there were discussions about the advantages and disadvantages of using expansive fiscal policy to stimulate economic growth, combining its instruments with monetary policy instruments, introducing restrictive fiscal rules. In addition, research on modeling fiscal policy in the context of determining its impact on economic growth is relatively standard. Public investment impacts long-term economic growth (Barro, 1990; Bah \& Kpognon, 2020; Nguyen \& Trinh, 2018). Other studies 
show that budget deficit harms economic growth in the long term (Adam \& Bevan, 2005; Arjomand et al., 2016; Molocwa et al., 2018; Tung, 2018). Besides that, the growth of external debt harms the state budget because external debt can lead to a debt trap (Kusumasari, 2020). Reinhart \& Rogoff (2010) conclude that if public debt increases by more than $90 \%$ of GDP, economic growth slows down. David (2017) shows that capital expenditures of the state budget have a significant effect on economic growth in Paraguay. Public debt had an impact on economic growth (Wibowo, 2017; Djulius, 2018). Dey \& Tarque (2020) reveal the negative impact of external debt on GDP growth.

In addition to empirical studies of fiscal policy, investigations that assess the features of applying theoretical postulates of fiscal theories in practice are worth noting. From among such works, Stawska (2017) whose indicates that the expansive fiscal policy, often caused by economic fluctuations, contributes to the deepening of the imbalance of public finances with frequent downturns in GDP. Restrictive policies improve the situation in the public finance sector from the long-term perspective, contributing to moderate economic growth. Stoilova \& Patonov (2020) prove that taxation is a more reliable instrument than government spending in a small open emerging-market economy.

Benos (2009), examining the impact of fiscal policy on economic growth in European countries, notes the importance of the structure of public spending. After all, state budget expenditures on infrastructure and defense have a positive impact on economic growth. An increase in the tax burden suppresses economic growth. Besides that, expenditures on education and the social sphere do not significantly impact economic development. David (2019) also emphasizes the importance of capital expenditures for economic development. The development of the country's infrastructure leads to the growth of all industries involved in its construction and maintenance. Infrastructure in the key factors that determine economic growth (Esfahani \& Ramírez, 2003; Palei, 2015; Khan et al., 2020)

Publications concerning the assessment of fiscal rules occupy a rather important place in studying the role of fiscal policy in economic development. For instance, Działo (2012) shows that the use of fiscal rules positively impacts economic growth and macroeconomic stability. They allow reducing excessive political pressure on the state budget towards increasing its deficit and public debt to finance political programs. Fiscal rules are beneficial for macroeconomic stability (Gomez-Gonzalez et al., 2021). Nizioł (2018) proves that, in addition to fiscal discipline in public spending, the fiscal rule effectively limits the growth of public debt, which has a positive effect on macroeconomic stability. Ardanaz et al. (2021) state that fiscal rules are flexible if they include features to accommodate exogenous shocks.

Owsiak's (2016) work deserves considerable attention, in which a thorough analysis of the development of the Polish tax system. The conclusion is that Moderate fiscals characterize Poland's tax policy; shrinkage of tax thresholds for personal income tax has harmed state budget revenues. Therefore, Poland needs to expand the number of such "thresholds" to the level of advanced countries with long-continued tax traditions, where 
there is a progressive tax scale. The reconstruction of the tax system should aim to support a relative balance between direct and indirect taxes, which will make it possible to return to the more significant role of direct taxes in reducing excessive income inequality in society. The effectiveness of the tax system and fiscal policy depends on the people who implement this policy. The emphasis on the subjects of the implementation of fiscal or tax policy is essential in analyzing the effects of fiscal policy on economic development, forasmuch as it takes into account the qualitative component of the policy.

When it comes to scientific research of the fiscal policy of Ukraine in the context of its impact on economic development, it is worth noting the publication of Shevchuk \& Kopych (2018) conclude that the advisability of an income-based financial consolidation policy in Ukraine, forasmuch as better tax collection can contribute to economic growth even in the short term perspective. Grazhevskaa \& Virchenkoa (2014) prove the significant dependence of the effectiveness of the mechanism of fiscal policy transfer in the Ukrainian economy on such institutional factors as public expenditure management, consumer expectations, and the level of fiscal decentralization.

This research will provide policy recommendations for economic development in the two countries. Based on the various studies above, it shows that fiscal policy has a significant impact on economic development in a country. Thus, the contribution of this research is to provide recommendations for appropriate fiscal policies in each country to improve the development process in each country.

\section{Methods}

The following methods have been used in the course of the research, namely: First, synthesis analysis - in studying the scientific literature and determining the directions of the impact of fiscal policy on economic development. The second step is doing economic and statistical analysis and comparison while studying the dynamics of economic development of Ukraine and Poland. Next, we do economic and mathematical methods while studying correlation relationships between economic development indicators and fiscal policy indicators in Ukraine and Poland. Finally, we generalize -to form scientifictheoretical and practical recommendations for improving the fiscal policy of Ukraine because of the experience of Poland.

\section{Result and Discussion}

The comparative characteristics of the fiscal policy of economic development of Poland and Ukraine will not be complete if we leave untouched the fundamental indicators determining the economic development of these countries (see Table 1). Thus, the dynamics of GDP and the dynamics of GDP per capita are such indicators, forasmuch as they indicate the overall level of economic development. According to data of Table 1, Poland is four to five times better than Ukraine in terms of GDP and GDP per capita, which is a phenomenal result taking into account the common historical past (as of 1990, Poland's GDP was 69, 98 billion USD and Ukraine's GDP was 81,46 
billion USD) and almost the same starting conditions for economic development after the collapse of the USSR.

\begin{tabular}{|c|c|c|c|c|c|c|c|c|c|c|c|c|c|c|c|c|c|}
\hline 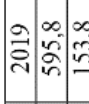 & 瓷 & $\begin{array}{l}\text { 㤩 } \\
\text { 总 }\end{array}$ & & & & & $\vec{i}$ & $\hat{\alpha}$ & & 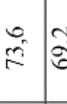 & & 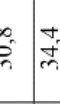 & $\begin{array}{l}0 \\
80\end{array}$ & 晃 & 宔 & 离 & $\begin{array}{l}\infty \\
\stackrel{n}{\Omega}\end{array}$ \\
\hline 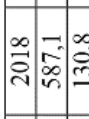 & 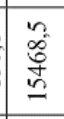 & 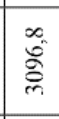 & & & & 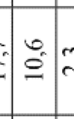 & $r$ & $\stackrel{\circ}{\therefore}$ & $\bar{s}$ & \begin{tabular}{l|l}
$\stackrel{F}{*}$ & $\bar{\alpha}$
\end{tabular} & & $=\frac{\partial}{m}$ & $\overline{\hat{\delta}}$ & ণิ & $\begin{array}{l}0 \\
f\end{array}$ & $\bar{\sigma}$ & ू̆ \\
\hline 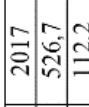 & 趸 & 亳 & ปี & $\vec{i}$ & & $=\cong$ & & $\stackrel{+}{\stackrel{2}{\sim}}$ & ते| & 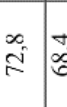 & & 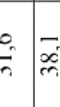 & $\frac{2}{6}$ & $\frac{0}{\vec{N}}$ & $\begin{array}{l}0 \\
\text { ing }\end{array}$ & $\begin{array}{l}\infty \\
\infty \\
\infty\end{array}$ & : \\
\hline 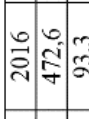 & 竞 & $\frac{\tilde{x}}{\pi}$ & il & 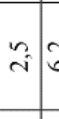 & & $\stackrel{\text { s. }}{\mathrm{I}}$ & & 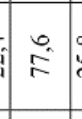 & $\mid$ & 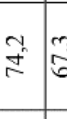 & & $c=$ & $\begin{array}{l}n \\
f \\
f\end{array}$ & 섯 & 品 & $\begin{array}{l}\infty \\
\infty \\
\infty \\
\infty\end{array}$ & $\begin{array}{l}0 \\
\text { s. }\end{array}$ \\
\hline : & 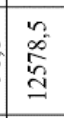 & 等 & & $\vec{i}$ & & $\underbrace{\infty}_{0}$ & & $=$ & $\mid$ & $\begin{array}{cc}m \\
\approx\end{array}$ & & $\hat{7}$ & in & & 定 & $\ddot{\infty}$ & 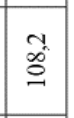 \\
\hline 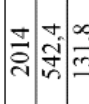 & 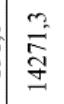 & 过 & in & $\stackrel{\infty}{i}:$ & & 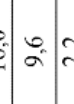 & & 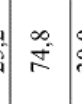 & : & 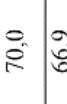 & & $=6$ & in & త్ & 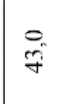 & $\begin{array}{l}\stackrel{.}{\infty} \\
\approx\end{array}$ & $\stackrel{\infty}{\tilde{\Xi}}$ \\
\hline 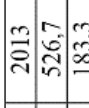 & 总 & 宒 & i) & $\Rightarrow$ & & $=0$ & 0 & 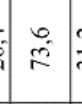 & $\approx$ & 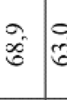 & & $\begin{array}{ll}0 \\
n \\
n\end{array}$ & $\begin{array}{l}n \\
\text { f } \\
i n\end{array}$ & $\stackrel{\overbrace{}}{\mathrm{\gamma}}$ & $\begin{array}{l}0 \\
\dot{\sigma}\end{array}$ & $\begin{array}{l}\infty \\
\propto \\
\propto\end{array}$ & $\overrightarrow{5}$ \\
\hline 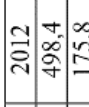 & 旁 & 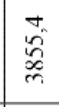 & ה̇ & $\vec{i}=\vec{r}$ & & $=\underset{\infty}{\infty}=$ & & 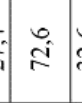 & |cîn: & 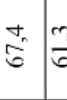 & & 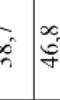 & $\tilde{n}$ & $\stackrel{\circ}{+}$ & $\begin{array}{l}0 \\
\text { f }\end{array}$ & s. & $\begin{array}{l}0 \\
\stackrel{0}{0}\end{array}$ \\
\hline & 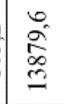 & $\begin{array}{l}\infty \\
0 \\
\hat{心} \\
m \\
m\end{array}$ & $\vec{\nabla}$ & $\Rightarrow$ & & $=0$ & & $\overrightarrow{+}$ & ले & $\begin{array}{ll}E \\
\tilde{s}\end{array}$ & & $\begin{array}{ll}0 \\
0 \\
0 \\
n\end{array}$ & $\begin{array}{l}n \\
q \\
q\end{array}$ & $\vec{i}$ & $\begin{array}{l}0 \\
\text { J }\end{array}$ & है & \begin{tabular}{|l}
$\infty$ \\
$\stackrel{\infty}{\Theta}$ \\
$\stackrel{8}{\Theta}$
\end{tabular} \\
\hline 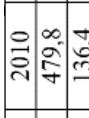 & 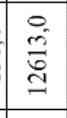 & 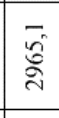 & $=$ & ते & & $\therefore$ & & $\vec{f}$ & तें & 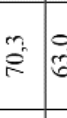 & & $\begin{array}{ll}0 & n \\
n & n\end{array}$ & $\stackrel{n}{q}$ & ते & $\begin{array}{l}0 \\
\text { is } \\
\text { in }\end{array}$ & $\stackrel{t}{\&}$ & $\bar{\Omega}$ \\
\hline 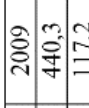 & 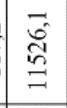 & 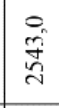 & $\overrightarrow{\mathrm{A}}$ & is & & o. & & 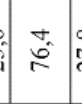 & 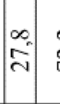 & 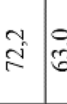 & & $\bar{n}$ & $\vec{\partial}$ & $\stackrel{\circ}{\vec{i}}$ & $\begin{array}{l}0 \\
f\end{array}$ & हु & 气̂ \\
\hline 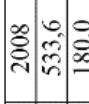 & 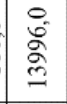 & 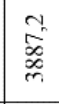 & $=$ & i: & & 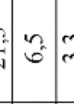 & & 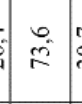 & हि & $\begin{array}{c}m \\
3 \\
0\end{array}$ & & $\begin{array}{l}* \\
\dot{*}\end{array}$ & $\vec{n}$ & $\stackrel{\vec{i}}{\vec{i}}$ & 足 & $\stackrel{2}{=}$ & $\stackrel{\circ}{\circ}$ \\
\hline ปิ่ & 等 & $\begin{array}{l}0 \\
0 \\
0 \\
0 \\
0\end{array}$ & $\overrightarrow{\vec{\lambda}}$ & $\therefore$ & & 3 & 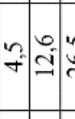 & $s$ & : & 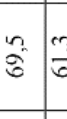 & & 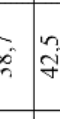 & $\frac{n}{n}$ & $\stackrel{\vec{i}}{\vec{i}}$ & $\begin{array}{l}0 \\
F\end{array}$ & $\stackrel{\circ}{\stackrel{\circ}{\circ}}$ & $\stackrel{\infty}{\sigma}$ \\
\hline 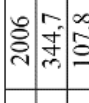 & 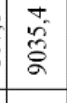 & 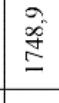 & $\vec{i}$ & & & $\therefore=$ & & $\vec{ि}$ & 앙- & 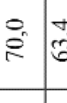 & & $\begin{array}{ll}0 \\
\dot{n}\end{array}$ & ñ & ণิ & \begin{tabular}{|l}
0 \\
$\infty$ \\
$\infty$ \\
$j$
\end{tabular} & 告 & ๙ే \\
\hline $\mid$ & 号 & 管 & î & ते & & $\alpha_{\infty}$ & 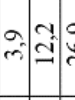 & $\overrightarrow{8}$ & 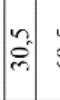 & $\begin{array}{c}n \\
8 \\
8\end{array}$ & & $\begin{array}{ll}0 \\
0\end{array}$ & 离 & में & $\therefore$ & ते & నో \\
\hline 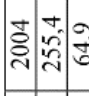 & 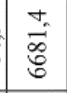 & 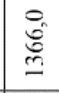 & ป̂ & $m$ & & $\stackrel{\leftrightarrow}{\subseteq}$ & & $=$ & ते & $\begin{array}{ll}\vec{a} \\
\vec{a}\end{array}$ & & $=\frac{3}{n}$ & $\vec{g}$ & ì & $\underset{\mathrm{d}}{\mathrm{j}}$ & 药 & $\stackrel{\circ}{\stackrel{0}{*}}$ \\
\hline 总 & 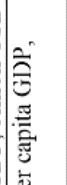 & 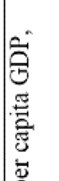 & 䇏 & 意 & & 耪 & 莺 & 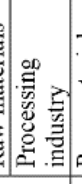 & 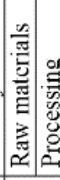 & 思 & & 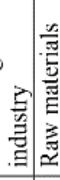 & $\begin{array}{l}0 \\
0\end{array}$ & 莀 & & & 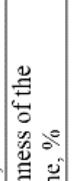 \\
\hline 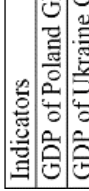 & 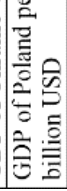 & 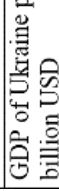 & & 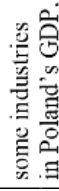 & & 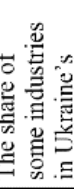 & 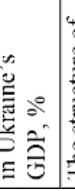 & 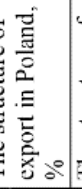 & 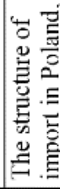 & & & & & 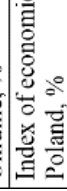 & 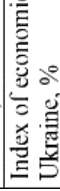 & 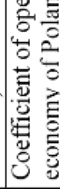 & 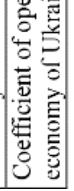 \\
\hline
\end{tabular}


The data comparing the indicators of economic development of Ukraine and Poland. Table 1 shows that Poland achieves high results in GDP dynamics and GDP per capita due to the development of the industry. The data in Table 1 shows that there are negative trends in the structure of GDP in Ukraine. The share of the industry over the past 12 years has decreased by $5 \%$ to $17 \%$ of GDP. In Poland, on the other hand, this indicator is stable and ranges from 21-22\% of GDP. Beyond that, it should note that the share of construction in Poland's GDP is significantly higher than in Ukraine, which indicates the focus of Poland's economic policy on the development of infrastructure. A high share in the structure of Ukraine's GDP is occupied by agriculture, which is relatively objective, taking into account agricultural land and soil fertility. However, agriculture is not an innovative industry that produces goods with high added value and can contribute to rapid economic growth. Trade-in these two countries is actually at the same level in the structure of GDP.

The structure of foreign trade in goods is an important indicator. After all, Ukraine's economy demonstrates a gradual transformation into a raw material appendage of advanced countries, forasmuch as the share of raw materials in the structure of exports by the end of 2019 amounts to 69,2\%. By contrast, in the structure of Poland's exports, $78,9 \%$ is accounted for exports of industrial products. As for imports, the indicators here are also quite unambiguous, forasmuch as in the structure of imports of Ukraine, 34,4\% is accounted for imports; previously this indicator was about 50\%. While in Poland, imports of raw materials account for $26,4 \%$ of total imports of goods. The high share of exports and imports of raw materials in Ukraine makes its economic development dependent on raw material cycles (see Figure 1).

Figure 1. Dynamics of price indices on raw materials and GDP of Poland and Ukraine in 2004-2019

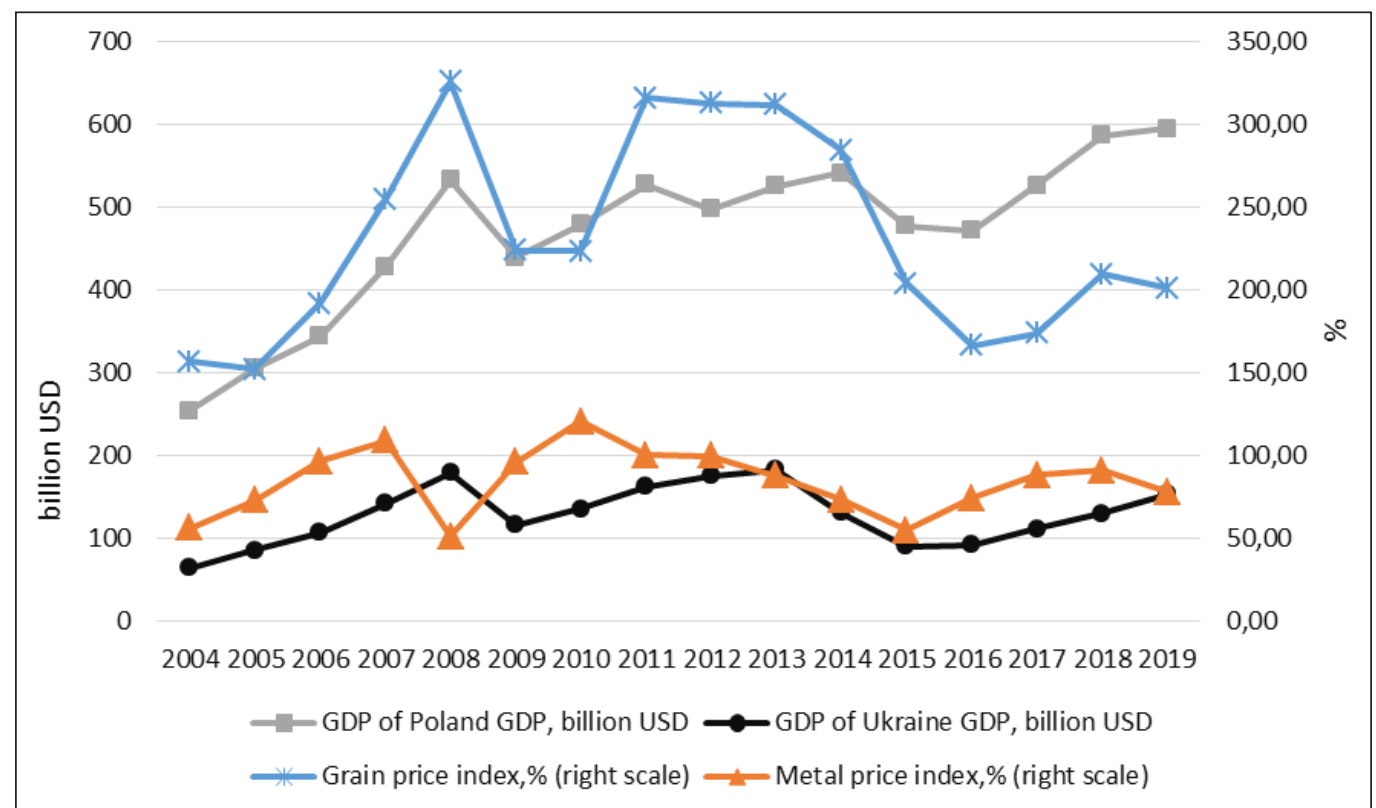

Source: Calculated by the author based on data: State Statistics Service of Ukraine: national accounts; Bank danych Makroeconomicznych: rachunki narodowe; Commodity Metals Price Index Monthly Price; FAO Food Price Index. 
According to data in Figure 1, the GDP of Ukraine almost repeats the dynamics of grain prices. It confirms with the correlation coefficient between these indicators, which is 0,8821 , while the correlation coefficient for Poland's GDP is significantly below - 0,5065. Regarding the correlation coefficients for the metal price index of GDP of Ukraine and Poland, it is 0,3310 and 0,1398, respectively. Changes in the dynamics of prices for raw materials significantly affect the profitability of ferrous metallurgy and agriculture enterprises in Ukraine that are the leading exporters of raw materials to international commodity markets; this, in turn, negatively affects the dynamics of GDP.

Conducting a brief analysis of the economic development of Ukraine and Poland, it is worth noting the dynamics of such an indicator as to the index of economic complexity, which reflects the number of complex products in the country's production. The complexity of the product means a measure of the amount of technology used to manufacture the product and expresses the value added. According to this indicator, Poland twice exceeds Ukraine, which means that its industry has a higher level of technology, and manufacturing plants produce goods with a higher level of value-added, which is the basis of economic development. In addition, the coefficient of openness of the economy is a vital indicator for comparing Ukraine and Poland in terms of the level of economic development, forasmuch as it reflects the ratio of the volume of foreign trade in goods and services to GDP. According to this indicator, Ukraine is also inferior to Poland. This data indicates the actual absence of the domestic market because production is export-oriented and consumption is imported.

Thus, based on the analysis of the trends mentioned above in the economic development of Poland and Ukraine, the inference should be drawn that Ukraine needs to pursue a policy of stimulating the development of industry and production of goods with value-added, reduce the share of raw materials in exports and increase the share of capitalintensive industries. Achieving these goals is impossible without implementing effective fiscal policy and taking into account international experience in this area. Therefore, a comparison of the fiscal policies of Poland and Ukraine should take place, taking into account the existing problems and opportunities of the economies of these states. It is essential to identify the vectors of fiscal policy to answer whether fiscal policy considers existing trends in the economy and whether it is aimed at creating conditions for further economic development.

In a general sense, fiscal policy regulates the state's revenues and expenditures to influence aggregate demand and national income or gross domestic product. In practice, fiscal policy is implemented through deficit financing of aggregate demand, establishing the structure of state budget expenditures and public investments, pursuing debt policy, implementing income policy, and administering taxes. Using these instruments, we will carry out a comparative analysis of the fiscal policy of economic development of Poland and Ukraine applying the methods of correlation analysis (Table 2 and 3). Taking into account the postulates of Keynesian theory, the analysis of deficit financing of aggregate demand is one of the directions of the analysis of the fiscal policy of Poland. However, the Polish government did not use this method from 2004 to 2019, forasmuch as 
the indicator of correlation between the dynamics of the state budget deficit and the dynamics of GDP is not significant.

At the same time, based on the analysis of the structure of public expenditure and debt policy, it should be noted that in Poland, the principle of functional finance is used, described in A. Lerner's theory. Thus, Table 2 shows that the correlation coefficient between capital and current expenditures of the state budget and GDP is significant. The higher correlation coefficient is observed between current expenditures and entirely objective GDP because the time lag of the impact of current expenditures on GDP is less than the time lag of the impact of capital expenditures used to finance economic infrastructure, which is the core basis of economic development. However, implementing infrastructure projects takes much longer than the growth of final consumption that increases current expenditures.

Table 2. Correlation matrix of indicators of fiscal policy of Poland's economic development in 2004-2019

\begin{tabular}{|c|c|c|c|c|c|c|c|c|c|c|c|}
\hline & 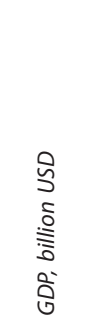 & 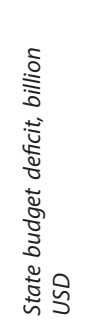 & 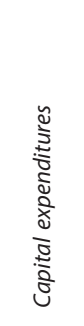 & 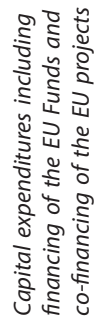 & 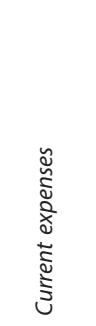 & 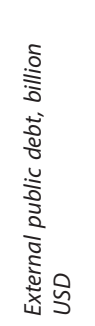 & 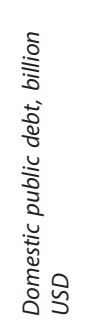 & 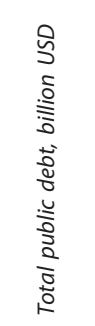 & 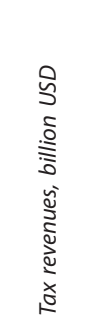 & 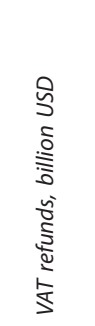 & 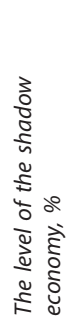 \\
\hline GDP, billion USD & 1 & & & & & & & & & & \\
\hline State budget deficit, billion USD & $-0,2789$ & 1 & & & & & & & & & \\
\hline Capital expenditures & 0,7145 & $-0,2147$ & 1 & & & & & & & & \\
\hline $\begin{array}{l}\text { Capital expenditures including } \\
\text { financing of the EU Funds and } \\
\text { co-financing of the EU projects }\end{array}$ & 0,6141 & $-0,1275$ & 0,7814 & 1 & & & & & & & \\
\hline Current expenses & 0,9184 & $-0,1774$ & 0,7714 & 0,8493 & 1 & & & & & & \\
\hline External public debt, billion USD & 0,7887 & 0,0333 & 0,4209 & 0,1984 & 0,5889 & 1 & & & & & \\
\hline $\begin{array}{l}\text { Domestic public debt, billion } \\
\text { USD }\end{array}$ & 0,9514 & $-0,0923$ & 0,7006 & 0,6874 & 0,9528 & 0,7359 & 1 & & & & \\
\hline Total public debt, billion USD & 0,9542 & $-0,0524$ & 0,6441 & 0,5536 & 0,8821 & 0,8807 & 0,9688 & 1 & & & \\
\hline Tax revenues, billion USD & 0,9649 & $-0,4285$ & 0,7755 & 0,7075 & 0,9383 & 0,6246 & 0,9155 & 0,8690 & 1 & & \\
\hline VAT refunds, billion USD & 0,8652 & $-0,5396$ & $-0,0094$ & $-0,4228$ & 0,5671 & 0,4760 & 0,4580 & 0,5784 & 0,7250 & 1 & \\
\hline $\begin{array}{l}\text { The level of the shadow } \\
\text { economy } \%\end{array}$ & $-0,6731$ & 0,3696 & $-0,5064$ & $-0,1171$ & $-0,4131$ & $-0,6717$ & $-0,4782$ & $-0,5803$ & $-0,6061$ & $-0,6065$ & 1 \\
\hline
\end{tabular}

Source: calculated by the author on the basis of data: Bank danych Makroeconomicznych; Sprawozdanie z wykonania budżetu państwa.

Analyzing the policy of expenditures of Poland's state budget, it notes that an essential element that has no analogs in Ukraine, namely: the financing of infrastructure projects at the expense of the funds of the European Union and co-financing of projects of the European Union at the expense of the Polish budget. Such measures automatically increase the share of capital expenditures in the state budget structure (see Figure 2). 
Figure 2. The Structure of Expenditures of The State Budgets of Poland and Ukraine by Elements in 2004-2019

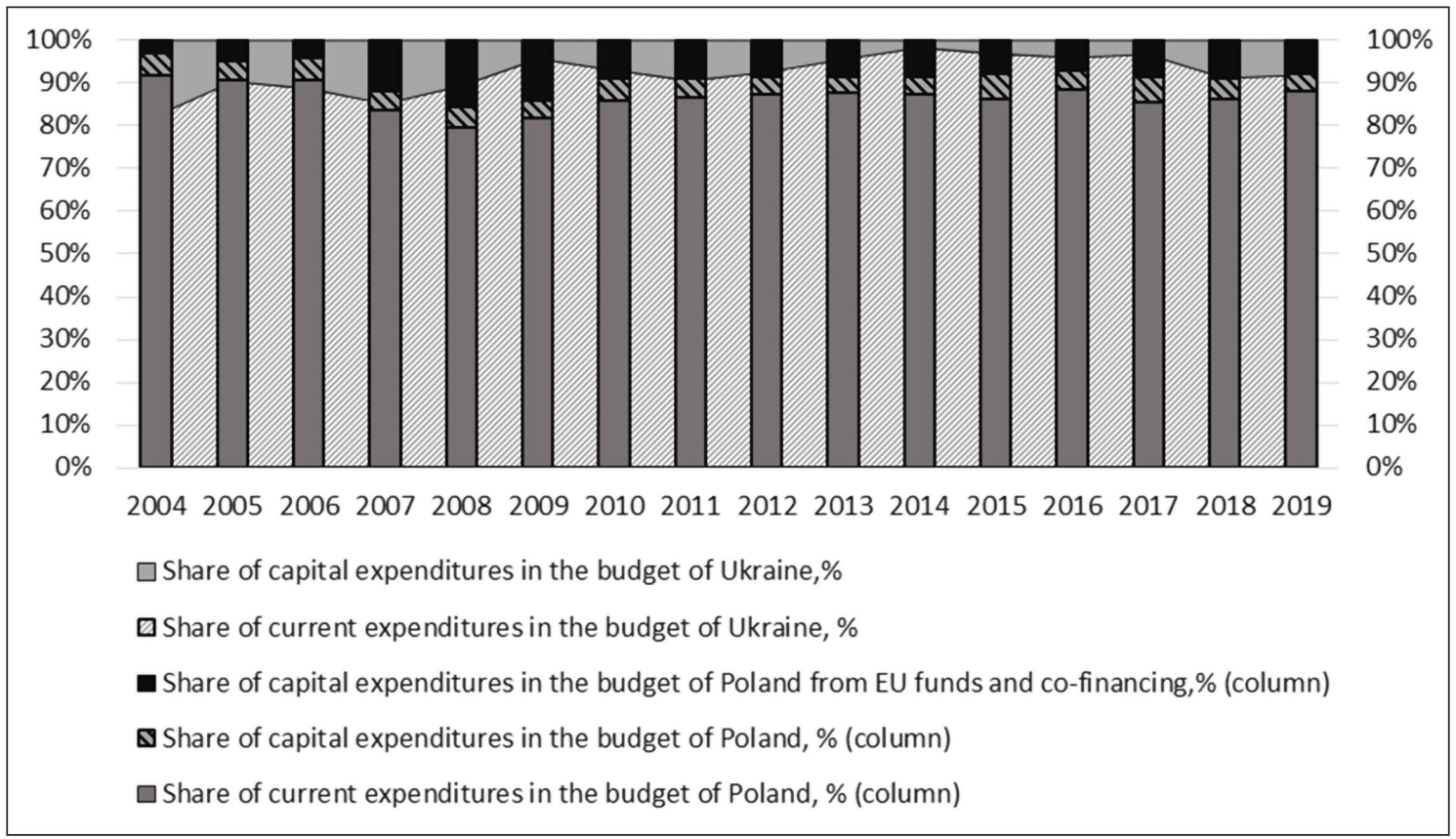

Source: calculated by the author based on data: Sprawozdanie z wykonania budżetu państwa; Budget of Ukraine.

The data in Figure 2 indicate that in 2004-2009 Ukraine dominated Poland in terms of the share of capital expenditures in the total expenditures of the state budget. However, the accession of Poland to the European Union in 2004 allowed using two additional clauses of capital expenditure, namely: expenditures of the European Union Funds and allocation of funds for co-financing of projects implemented under the EU convergence policy. Therefore, since 2004, Poland has been gradually increasing capital expenditures at the expense of the European Union. The example of Poland is especially indicated in the context of overcoming the consequences of the financial and economic crisis of 2008-2009 when capital expenditures were increased to finance the development of infrastructure (primarily transport), which made it possible to attract related sectors of the economy by raising the level of economic activity and aggregate demand. At the same time, it should note that fiscal policy is a change in the volume or share of financial resources directed to the economy and primarily the decisions of people in power at a particular time. No wonder, according to the Greek word, politics is the art of governing. The increase in capital expenditures due to an increase in funds for co-financing the EU projects and attracting funds from the EU funds provides for targeted financing of the infrastructure development of the Polish economy, in particular, the construction of roads and highways, social institutions, industrial complexes, and shopping hubs; consequently, this directly affects the share of construction in GDP, and, thus, contributes to economic development.

In contradiction from Poland, Ukraine does not have the opportunity to raise funds from the EU funds, the targeted use of which is strictly controlled (including corruption); as a result, this does not increase capital expenditures in the face of a crisis 
in the national economy. Such trends show in Figure 2, where during the economic crisis of 2014-2017 in Ukraine due to the war with the Russian Federation, the share of capital expenditures approached zero.

According to data of Table 2, debt policy plays an essential role in the fiscal policy of Poland's economic development, forasmuch as the correlation indicators between total public debt and GDP have a strong relationship (R2=0,9542). In contrast, the correlation indicators of domestic public debt are higher than the correlation indicators of external public debt and GDP. In contrast with Poland, the fiscal policy of economic development of Ukraine is radically different (see Table 3); after all, the primary emphasis is placed on deficit financing, the dynamics of capital expenditures has a medium correlation with GDP, and debt policy indicators are almost not correlated with the dynamics of GDP.

\section{Table 3. Correlation Matrix of Indicators of Fiscal Policy of Economic Development of Ukraine} in 2004-2019

\begin{tabular}{|c|c|c|c|c|c|c|c|c|c|c|}
\hline & $\begin{array}{l}\text { जิ } \\
\delta \\
\vdots \\
\vdots \\
\vdots \\
\text { ல }\end{array}$ & 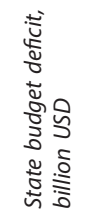 & 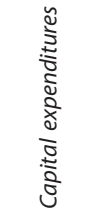 & 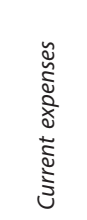 & 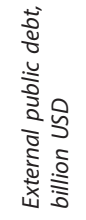 & 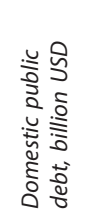 & 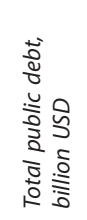 & 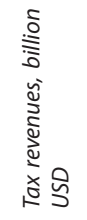 & 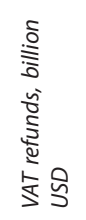 & 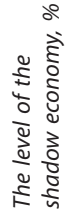 \\
\hline GDP, billion USD & 1 & & & & & & & & & \\
\hline State budget deficit, billion USD & 0,5131 & 1 & & & & & & & & \\
\hline Capital expenditures & 0,5555 & $-0,1586$ & 1 & & & & & & & \\
\hline Current expenses & 0,9504 & 0,6388 & 0,3211 & 1 & & & & & & \\
\hline External public debt, billion USD & 0,2955 & 0,2813 & $-0,2897$ & 0,5190 & 1 & & & & & \\
\hline $\begin{array}{l}\text { Domestic public debt, billion } \\
\text { USD }\end{array}$ & 0,4085 & 0,5196 & $-0,3203$ & 0,6396 & 0,9051 & 1 & & & & \\
\hline Total public debt, billion USD & 0,3553 & 0,3990 & $-0,3110$ & 0,5877 & 0,9803 & 0,9713 & 1 & & & \\
\hline Tax revenues, billion USD & 0,9675 & 0,4131 & 0,4971 & 0,9427 & 0,4354 & 0,4744 & 0,4641 & 1 & & \\
\hline VAT refunds, billion USD & 0,9187 & 0,5679 & 0,3760 & 0,9368 & 0,5002 & 0,5744 & 0,5469 & 0,9162 & 1 & \\
\hline $\begin{array}{l}\text { The level of the shadow } \\
\text { economy, } \%\end{array}$ & 0,1365 & 0,6053 & $-0,5482$ & 0,3032 & 0,4128 & 0,4185 & 0,4255 & 0,1552 & 0,2096 & 1 \\
\hline
\end{tabular}

Source: calculated by the author according to the data of State Statistics Service of Ukraine; Budget of Ukraine.

As the data in Table 3 evidence, Ukraine's fiscal policy is based on deficit financing of economic development. After all, there is an average level of correlation relationship between the dynamics of the state budget deficit and GDP and between the state budget deficit and current expenditures, which in turn have a significant correlation relationship with GDP. The mean level of the relationship between the state budget deficit and GDP can explain the consequences of the economic crisis of 2014-2017 caused by the war with the Russian Federation and internal political and economic imbalances, which has harmed the dynamics of macroeconomic indicators.

Comparing the policy of state budget expenditures and the debt policy of Ukraine and Poland, it should note that there is a clear and constitutionally established debt 
fiscal rule in Poland (limitation of public debt at the level of $60 \%$ of GDP and the use of intermediate triggers of public debt -50 and $55 \%$ of GDP). Along with this, the fiscal rules of the EU supranational government are in force (limiting the state budget deficit at 3\% of GDP, structural budget at 1\% of GDP), which, despite some criticism in Polish scientific circles, ensure a sufficient level of fiscal discipline in the country. At the same time, and what is especially important, the Polish government is obliged to comply with supranational fiscal rules by using the following sound prudential practices, namely: opening an excessive deficit procedure; directing governments towards reducing structural deficits; setting annual rates of debt reduction; the government's obligation to take fiscal rules into account when conducting fiscal policy.

Therefore, analyzing the data in Table 2, we can conclude about the successful fight against political pressure towards motivating the government to fulfill the populist wishes of deputies in the field of financing social expenditures, which constitute the basis of current expenditures of the Polish state budget; after all, there is no correlation relationship between the dynamics of the budget deficit and the dynamics of current expenditures.

Ukraine also has certain fiscal constraints, which the Budget Code of Ukraine determines. The constraints are the state budget deficit for each year of the mediumterm may not exceed 3 percent of the projected nominal GDP of Ukraine for the corresponding year; total public debt and guaranteed state debt at the end of the budget period can not exceed $60 \%$ of annual nominal Ukraine's GDP. However, in contrast to Poland, where the European Commission in Ukraine monitors the process of enforcing the rules, such measures are not carried out in practice, which leads to a violation of fiscal discipline.

In terms of debt policy, the data in Table 3 make it possible to conclude debt financing of the budget deficit and the lack of correlation between public debt and its structural elements and GDP. After all, based on the data in Table 3, an intermediate level of correlation relationship between the budget deficit and current expenditures is observed, while there is no correlation between the budget deficit and capital expenditures. However, the relative indicators of public debt indicate a higher level of debt dependence in Ukraine than in Poland (see Figure 3).

According to data in Figure 3, the absence of a debt rule in Ukraine led to a significant increase in debt dependence in 2014-2018; after all, the ratio of public debt to GDP exceeded 60\%. In addition, as contrasted with Poland, Ukraine's debt policy is aims to attracting external debt. The share of total public debt is more than $60 \%$. While in Poland, the share is only 30-35\%. The attraction of Ukraine's external public debt in foreign currency has an objective explanation, taking into account the openness of the national economy, dependence on imports, primarily on energy resources. However, in contrast to Poland, where all external public debt is attracted on the international money and capital markets, $20-30 \%$ of Ukraine's external public debt is owed to international financial institutions. 
Figure 3. Dynamics of debt policy indicators of Poland and Ukraine in 2004-2019

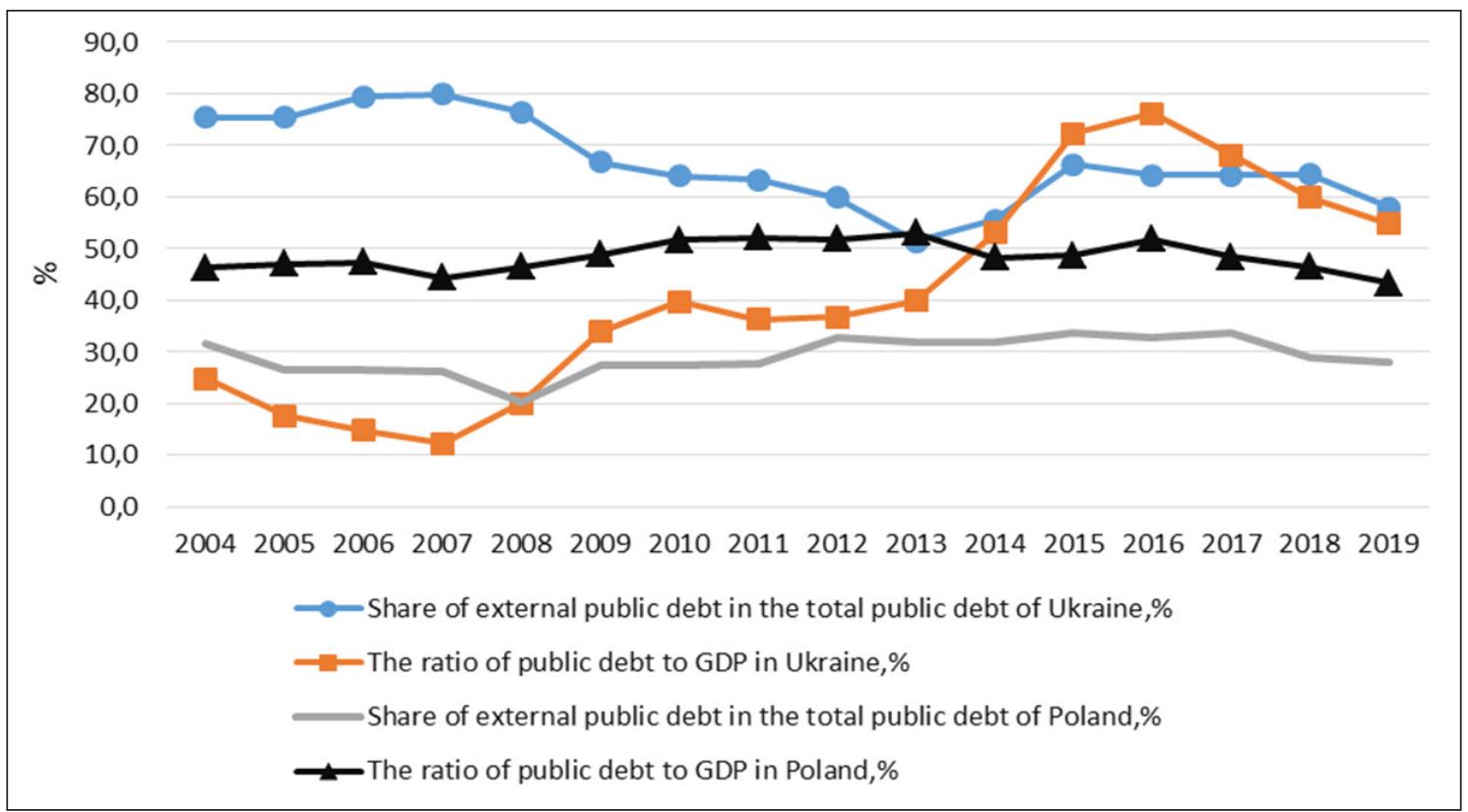

Source: calculated by the author according to the data of State Statistics Service of Ukraine; Bank danych Makroeconomicznych.

In terms of the cost of servicing external debt, borrowing from international financial institutions is a justified strategy for debt policy. However, it should note that international financial institutions provide loans to the state. In addition to financial commitments, often involve political commitments that may be contrary to national interests, such as increase of tariffs for communal services without modernization of heat supply, adoption of laws on land reform without the creation of proper infrastructure of regulation of the market of agricultural lands; prohibition to impose export and import duties on specific groups of goods. From these perspectives, the debt policy of Ukraine needs to be optimized to reduce external debt dependence on international financial and credit organizations.

In addition, comparing the debt policy of Poland and Ukraine, it should be noted that the correlation relationship between debt policy and Poland's GDP is relatively high, which indicates the debt financing of economic development and a high level of conversion of public debt into economic development. Herewith, the high share of domestic debt in the structure of Poland's public debt creates opportunities for the government to carry out mutual writing off debts in the event of an aggravation of crisis phenomena in the economy. In Ukraine, the situation is entirely different: public debt dynamics are not related to GDP dynamics, which indicates the inefficient use of debt resources for stimulating economic growth.

In addition to expenditure and debt policies, an essential element of fiscal policy is revenue policy. This fiscal policy is implementing through tax policy. Consequently, analyzing the data on the correlation dependences of tax revenues and GDP of Poland and Ukraine, we can conclude about the significant role of taxes in states' economic development. The same applies to VAT refunds as a tax benefit, the dynamics of which has a significant correlation relationship with the dynamics of GDP in both countries. 
As an element of fiscal policy, income policy is essential for economic growth, forasmuch as it affects aggregate demand through changes in tax rates, the mechanism of tax administration, and the formation of the structure of tax revenues. Regarding the types of taxes, the tax systems of Poland and Ukraine are approximately the same. The differences lie in applying taxes that are insignificant in terms of mobilization of funds to the Polish budget, such as forest, vehicle, and tax on games.

There are differences in the personal income tax, which in Poland has two thresholds: if earnings during the year have amounted to less than 85528 PLN, the tax rate is $18 \%$; if earnings during the year have amounted to more than 85528 PLN, the tax is $32 \%$. There is a simplified progressive system of personal income taxation in Poland, which, on the one hand, considers the principles of social justice. On the other hand - it leads to higher budget revenues. In Ukraine, there is a simple system of personal income taxation, which provides a tax rate of $18 \%$ regardless of the number of wages, which introduces significant imbalances in the tax burden on employees who receive the minimum wage.

Figure 4. Dynamics of the share of consumption taxes and final consumer expenditures in Ukraine and Poland in 2004-2019

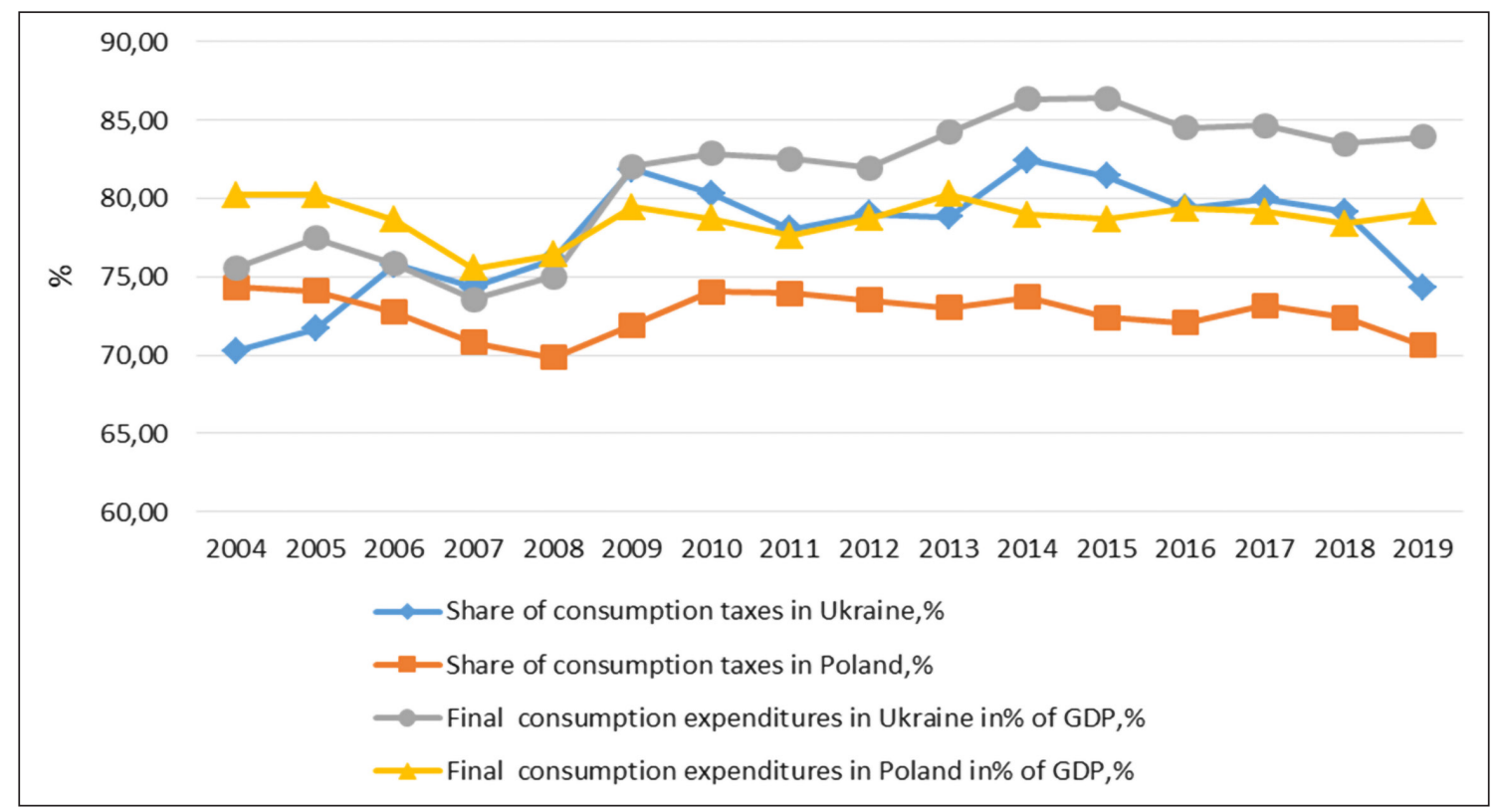

Source: Calculated by the author according to the data of State Statistics Service of Ukraine; Bank danych Makroeconomicznych.

In terms of the structure of tax revenues, in our opinion, it is ineffective both in Poland and in Ukraine, forasmuch as consumption taxes are more than $70 \%$ and $80 \%$, respectively. The high level of fiscal consumption is since the basis of the GDP of both countries is made up of final consumption expenditures, and gross capital formation occupies an insignificant share (Figure 4).

According to Table 4, the share of consumption taxes exceeds in Ukraine the same indicator in Poland by $10-12 \%$. Along with this, the share of final consumer expenditures 
in GDP is about $85 \%$, which indicates negative trends in economic development and the short-term effects of fiscal policy. The increase in the share of consumption taxes indicates a decrease in the base of taxes on income. In turn, it concludes about a decrease in the number of enterprises and employment in Ukraine. What is more, the high level of final consumption expenditures in Ukraine indicates a low share of gross capital accumulation, which is the basis of economic growth, and, therefore, requires fiscal policy to use instruments that would stimulate production. Such instruments include public investments, which are implemented through the mechanism of capital expenditures within the framework of state development programs, providing targeted financing, and preferential taxation of certain types of entrepreneurial activity.

We have considered the trends of capital expenditures hereinbefore. However, it should note that the results of such expenditures in Poland are higher than in Ukraine, forasmuch as the lion's share is implemented at the expense of the European Union Funds and through co-financing mechanisms of the EU projects under strict monitoring for targeted use.

Regarding tax incentives, both in Poland and in Ukraine, several tax benefits are using, among which it is worth noting those that have similar goals, namely: exemption from taxation of educational, cultural, medical, and sports institutions; exemption from taxation of medical technologies and medicines; exemption from taxation of goods for national security and defense. However, there are pretty significant differences in preferential taxation of industry and agriculture (Tables 4 and 5).

Analyzing the types of tax incentives for agricultural and non-agricultural enterprises in Poland, we can conclude that their concept is consistent with the general trends in the development of the Polish economy, forasmuch as none of the incentives aims to stimulate raw materials' production. On the contrary, the existing tax incentives aim to develop infrastructure, innovation, and the processing industry with a high share of added value. This approach is to the implementation of the entire fiscal policy of Poland that has led to a high level of economic development compared to Ukraine.

As for Ukraine, the tax policy also provides several benefits used for various sectors of the economy. Analyzing the Directory of tax benefits of Ukraine, we can conclude that in addition to benefits for education, culture, medicine, sports, and the social sphere, a significant number of benefits are used for industries involved in trade under interstate agreements on free trade zones, or within other interstate agreements. However, it is rather difficult to analyze the importance of such benefits for economic development because, on the one hand, there is no necessary statistical data. On the other hand, revisions will require the effects for the national economy from the activities of the existing free trade zones, which we will leave for further scientific research. In addition, it is worth noting the temporary tax benefits that apply to the production and trade of goods intended for national defense and the anti-terrorist operation in eastern Ukraine. 
Table 4. Groups of the Basic Tax Incentives for the Economy and Agriculture in Poland and Their Features

The role for economic development

\begin{tabular}{|c|}
\hline Groups of the tax incentives \\
\hline Incentives for agricultural enterpr \\
\hline $\begin{array}{l}\text { Exemption from taxation for the purchase of land up to } 100 \text { hectares to } \\
\text { create a new farm or expand an existing one. }\end{array}$ \\
\hline $\begin{array}{l}\text { Investment incentive for farmers for the construction or modernization of } \\
\text { livestock buildings for breeding and keeping farm animals and environmental } \\
\text { protection facilities; construction of drainage structures and purchase of a } \\
\text { water supply device for the farm; purchase of devices used for production } \\
\text { purposes for natural energy sources (wind, biogas, sun, falling water). The } \\
\text { investment incentive is granted after the completion of the investment. } \\
\text { It consists of a deduction from the agricultural tax on land located in the } \\
\text { commune where the investment was made - in } 25 \% \text {, documented using } \\
\text { investment accounts. However, incentives for the same investment cannot } \\
\text { be used for more than } 15 \text { years. }\end{array}$ \\
\hline $\begin{array}{l}\text { Tax incentives for farmers in mountainous areas and tax credits in the event } \\
\text { of a natural disaster. }\end{array}$ \\
\hline Income from the sale of farm real estate is exempt from taxation. \\
\hline $\begin{array}{l}\text { Income received from agritourism is exempt from personal income tax (rent } \\
\text { of rural houses, rooms in villages, etc.). }\end{array}$ \\
\hline $\begin{array}{l}\text { Income from the sale of processed agricultural products is exempt from } \\
\text { personal income tax. }\end{array}$ \\
\hline $\begin{array}{l}\text { Remuneration received by members of agricultural production cooperatives } \\
\text { for the use of land contributions by cooperatives is exempt from personal } \\
\text { income tax }\end{array}$ \\
\hline $\begin{array}{l}\text { A tax incentive for agriculture is applied, which consists in reducing the tax in } \\
\text { the first year by } 75 \% \text {, and in the second year by } 50 \% \text { in the case of acquiring } \\
\text { land or expanding an existing farm with an area of up to } 100 \text { hectares ( } 5 \\
\text { years), land resulting from the development of wastelands ( } 5 \text { years), and land } \\
\text { after exchange or consolidation ( } 1 \text { year). }\end{array}$ \\
\hline $\begin{array}{l}\text { Parts of arable land, meadows, and pastures resulting from soil reclamation } \\
\text { that led to the destruction of crops due to drainage works were exempted } \\
\text { from taxation by the agricultural tax. The exemption covers the tax year in } \\
\text { which the crops have been damaged. }\end{array}$ \\
\hline
\end{tabular}

Exemption from taxation for the purchase of land up to 100 hectares to create a new farm or expand an existing one. livestock buildings for breeding and keeping farm animals and environmental purposes for natural energy sources (wind, biogas, sun, falling water). The incentive is granted after the completion of the investment. commune where the investment was made - in 25\%, documented using investment accounts. However, incentives for the same investment cannot used for more than 15 years.

of a natural disaster.

Income from the sale of farm real estate is exempt from taxation.

Income received from agritourism is exempt from personal income tax (rent of rural houses, rooms in villages, etc.).

ncome from the sale of processed agricultural products is exempt from income tax

\section{Incentives for non-agricultural enterprises}

Accelerated depreciation. It is applied for small taxpayers (the amount of income from the sale of which for the previous year does not exceed 1,2 million EUR) and those taxpayers who start production. It is applied for the purchase of intangible assets, except for passenger vehicles. The write-off limit for depreciation may not exceed 50000 EUR during the tax year.

Expenses for the purchase of new technologies by taxpayers engaged in non-agricultural activities are exempt from taxation.

The settlement of investment loss for previous years, possibly write off tax payments in the current tax year and for the next five years, but not more than $50 \%$ in case of losses on a particular source of income in previous years.

Subsidies from local state budgets are exempt from taxation.

Tax credit. After submitting the relevant declaration and fulfilling the conditions provided by the Law on PIT (including support for a certain level of employment), taxpayers who have started a business for the first time are entitled to an annual exemption from the obligation to pay advances on income tax.

Income received from activities in special economic zones based on appropriate permits is exempt from taxation. A limited state aid quota is used.

Bio components are exempt from excise duty intended for liquid fuels, fuels with bio components, biocomponents that make up an independent fuel.

Production of electricity from renewable sources is exempt from excise duty. ax incentives are aimed at encouraging productive and organic farming, forasmuch as farms are again exempt from almost all types of tax.

From our viewpoint, the investment incentive applied to farms and family farms that build livestock buildings is essential for developing animal husbandry in Poland. In addition, in contrast to crop production, animal husbandry has a higher degree of added value and contributes to the introduction of organic fertilizers into the soil, which allows maintaining their quality at the proper level.

An incentive for the development of agritourism is quite an innovative benefit in the Polish tax system. In order to stimulate the development of wastelands, land reclamation is also an essential measure of the state for the development of agriculture as one of the drivers of economic growth and employment growth.
Tax incentives for non-agricultural enterprises aim to support investment activities carried out by small taxpayers and taxpayers who start their businesses. Such measures of the state encourage the creation of start-ups, the modernization of already established enterprises that positively affects a business climate.

Benefits to support innovation are important; they are applied to enterprises of various forms of ownership and of various sizes.

Benefits for producers of bio components, biofuels, electricity from renewable sources also stimulate innovation and production of goods with a high share of value-added.

Source: compiled by the author on the basis: Cel i mechanizm preferencji podatkowych. 
Tax incentives for enterprises are particular and, in our opinion, do not always correspond to the national objectives towards stimulating the economic development of Ukraine. Along with this, it should note that at the request of the International Monetary Fund. The special tax regime for activities in agriculture, forestry, and fisheries has been canceled. Consequently, in Ukraine, as contrasted with Poland, there are no tax incentives for the development of agriculture. In our viewpoint, it negatively affects the development of farms, family farm units, agricultural cooperatives, animal husbandry and the state of soils, and the social-economic situation in rural areas. The lack of benefits for agricultural enterprises leads to the development of high-margin agricultural raw materials production or primary processing, which does not help reduce the level of dependence of the Ukrainian economy on raw material cycles. In addition, the lack of support for animal husbandry and the development of agricultural infrastructure negatively affect the soil's quality due to the low level of organic fertilization. Consequently, in the long term, Ukraine runs the risk of losing the benefits of fertile black soil, which will undoubtedly affect the pace of economic development. The tax incentive for non-agricultural enterprises in Ukraine is shown in Table 5.

Based on the analysis of tax incentives for Ukrainian enterprises, we can conclude that there is no effective strategy for fiscal policy in particular and a strategy for the development of the state in general. After all, the existing tax incentives do not make it possible to modernize the national economy from a raw material appendage of the world's advanced countries to a competitive, innovative, and technological economy. This industry produces goods with a high level of added value.

Nowadays, the fiscal policy of Poland can be an exemplary example for the government of Ukraine in the field of optimization of fiscal policy. However, while borrowing the experience of Poland, one should not forget that those practical recipes for fiscal policy can work in Ukraine only if the legal support is at the same level. This condition refers to the quality of legislation, the efficiency of the judiciary, and tax authorities' efficiency. This conclusion confirms the correlation relationship between the level of the shadow economy and the GDP of Poland and Ukraine (see tables), forasmuch as in Poland, the decrease in the level of the shadow economy $(\mathrm{R} 2=-0.6731)$ leads to GDP growth. However, there is no relationship between such indicators in Ukraine. 
Table 5. Groups of the Basic Tax Incentives for the Economy of Ukraine and Their Features

Tax incentives in Ukraine
The income from which is exempt from taxation. Temporarily, until January 1, 2025,
the profit of the enterprises - the subjects of aircraft construction that are subject
to norms of article 2 of the Law of Ukraine, "On the development of the aircraft
industry" is exempt from taxation. The freed-up funds (tax amounts that are not paid
to the budget and remain at the disposal of the taxpayer) are used for research and
development work on aircraft construction, creation or re-equipment of the material
and technical base, increase in production, the introduction of new technologies.
The use of such funds must be related to the activities of the taxpayer.
Until December 31, 2021, the zero interest rate is applied to income taxpayers whose
annual income does not exceed three million hryvnias. Also, the amount of salary
(income) accrued for each month of the reporting period to each employee with
the taxpayer in labor relations is not less than two minimum wages, the amount
of which is established by law.
Temporarily, until January 1,2022, transactions on the supply of coal and/or products
of its commodity enrichment in the customs territory of Ukraine are exempt from
value-added tax.

Temporarily, until December 31, 2022, transactions on the supply of vehicles equipped exclusively with electric motors (one or more) in the customs territory of Ukraine are exempt from value-added tax.

Transactions on the sale of liquefied gas at specialized auctions for the population's needs are exempt from excise tax in the manner established by the Cabinet of Ministers of Ukraine.

The excise tax is levied at the rate of $0 \mathrm{UAH}$ per 1 liter of $100 \%$ alcohol from bioethanol used by enterprises to produce motor gasoline containing bioethanol, ethyl tert-butyl ether (ETBE), and other additives based on bioethanol.

Transactions on the sale of bodies for passenger vehicles in the customs territory of Ukraine are exempt from taxation, subject to the subsequent manufacture of vehicles from them.

The financial result before taxation is reduced: by the amount of the negative value of the object of taxation of the previous tax (reporting) years.

Land tax is not paid for land plots of agricultural enterprises of all forms of ownership and farms occupied by young orchards, berries, and vineyards before they entered into the period of fructification and hybrid plantations, gene pool collections, and nurseries of perennial orchards.

Transactions on the supply of services for fundamental investigations, research and development activities are exempt from taxation if a person directly receives payment for their value from the account of the body providing treasury services to the budget supplies such services and/or works.

Temporarily, until January 1, 2023, the subjects of space activities, which are subject to the Law of Ukraine "On Space Activities", are exempt from value-added tax on transactions for the supply in the customs territory of Ukraine of the results of scientific and research, development and construction works, which are performed for the needs of space activities. The Cabinet of Ministers of Ukraine shall establish the procedure for monitoring the register of scientific and research, development, and construction work to apply this privilege.

Temporarily until January 1, 2022, transactions on the supply of waste and scrap of ferrous and non-ferrous metals and paper and cardboard for recycling (waste paper and waste) are exempt from taxation. The Cabinet of Ministers of Ukraine approves lists of such waste and scrap of ferrous and non-ferrous metals.

Temporarily, until January 1, 2022, export transactions under the customs regime for the export of waste and scrap of ferrous and non-ferrous metals, as well as paper and cardboard for recycling (waste paper and waste) are exempt from taxation. The Cabinet of Ministers of Ukraine approves lists of such waste and scrap of ferrous and non-ferrous metals.

Petroleum products can be sold as raw materials for production in the chemical industry at a zero excise tax rate.

Transactions on the sale of tobacco raw materials to tobacco fermentation plants by persons who produce tobacco raw materials in the customs territory of Ukraine are exempt from taxation.

Transactions on the sale of fermented (processed) raw tobacco materials by tobaccofermentation plants to manufacturers of tobacco products are exempt from taxation.

A role for economic development

Analyzing the available tax benefits for Ukrainian enterprises, we can conclude that tax incentives for economic development in Ukraine are practically not implemented.

Thus, in the list of tax benefits, only four groups of tax incentives can be distinguished to contribute to economic growth. These are benefits for aircraft construction and the space industry, for horticulture and viticulture, for carrying out scientific and research activities, for the import of vehicle bodies for the production of cars in Ukraine.

Without contradiction, the aircraft and space industries are capitalintensive sectors with a high share of value-added. However, stimulating the development of one industry will not impact the overall economic growth of Ukraine. The same applies to the support of horticulture and viticulture.

It is worth noting the benefit for taxpayers, whose annual income, determined by the accounting rules for the last annual reporting period, does not exceed three million hryvnias, forasmuch as this tax preference somewhat facilitates the development of small and mediumsized businesses.

Privileges for the import of electric vehicles and biofuel production may positively affect the development of these sectors of the economy, however, not on the overall economic development.

Benefit concerning tax exemption for the import of car bodies is also ineffective, forasmuch as it stimulates imports rather than domestic production, and, therefore, has little effect on economic growth.

Most of the tax incentives in Ukraine aim to stimulate the production of raw materials, namely: ethyl alcohol, petroleum products; coal; waste and scrap of ferrous and non-ferrous metals; raw tobacco materials.

Source: Compiled by the author based on the Directory of tax benefits. 
A comparative analysis of the fiscal policy of economic development of Poland and Ukraine based on the application of a wide range of statistics has made it possible to conclude that there are fundamental differences between the regulatory approaches of both countries. The fact remains that Poland's fiscal policy aim to stimulate the development of infrastructure, an industry with a high level of added value, efficient agriculture by pursuing a policy of "functional finances" with a high level of conversion of public debt into economic growth. In Ukraine, the effects of fiscal policy on economic growth are insignificant, except for tax revenues and VAT refunds. Such tendencies can be connected with lobbying by deputies of interests of corporations dealing with raw materials during the drawing up of the State Budget of Ukraine.

The conducted economic and mathematical analysis of expenditures of the State Budget of Ukraine confirms the conclusion of Grazhevskaa \& Virchenkoa (2014) conclusion shows that the management of public expenditures is at a low level. Admittedly, more than $90 \%$ of expenditures from the State Budget of Ukraine are current expenditures; capital expenditures aimed at infrastructure development and laying the foundations for long-term economic development in a specific time amounted to $2-3 \%$.

This result confirms the conclusions of Działo (2012) on the importance of using fiscal rules in Poland and the positive impact of limiting the growth of public debt on macroeconomic stability. However, at the same time, the correlation analysis has shown that Poland's GDP directly depends on the dynamics of the domestic public debt. Stricter fiscal rules are associated with more sustainable fiscal policies (Bergman et al., 2016). Larch et al. (2021) show that deviation from fiscal rules and the accumulation of government debt foster pro-cyclical fiscal policy.

This conclusion is important for Ukraine, where it is advisable to introduce the rule of conversion of public debt into economic development, that is, to carry out public borrowing not only to finance the budget deficit but specifically for the implementation of a targeted state program towards stimulating economic growth. In this case, fiscal policy will significantly affect economic growth (Ahuja \& Pandit, 2020). However, the effect of public expenditures on growth is limited by the debt-to-GDP ratio (Teles \& Mussolini, 2014; Chen et al., 2017).

In addition, analyzing the experience of Poland in the field of public expenditure management, it is worth noting the significant role of the European Union in financing them through direct payments from the EU funds and by attracting co-financing from the budget of Poland for the implementation of the EU projects. Such collaboration in the capital expenditures of the state budget has allowed Poland to significantly improve its economic and transport infrastructure over the past 15 years, which in turn has created a basis for long-term economic development. Ukraine does not have such opportunities to attract grants from the European Union to increase capital expenditures in development. However, the high level of the shadow economy opens up prospects for fiscal consolidation in the area of revenues by increasing the efficiency of tax authorities and reducing regulatory pressure on the business. Government should do fiscal transparency to increase 
the government effectiveness (Montes et al., 2019). The public sector efficiency improves consolidation policies and outcomes (Heylen et al., 2013).

\section{Conclusion}

The analysis of the level of economic development of Poland and Ukraine has made it possible to conclude that Poland has dominated over Ukraine in terms of GDP by 4-5 times. Even though after the collapse of the Soviet Union, Ukraine somewhat overrode Poland in this respect. One of the reasons for such a rapid pace of economic development in Poland is an effective fiscal policy based on the concept of "functional finances," where the main emphasis is on capital expenditures on economic infrastructure; this is the basis of long-term economic growth, as well as fiscal discipline, which allows ensuring a high level of conversion of public debt into economic development. In addition, Poland's fiscal policy is characterized by an extensive system of tax benefits, which aims to stimulate the development of products with a high share of value-added. The result of the fiscal policy of Poland was the achievement of a high share of industrial products in exports, which significantly reduces the dependence of the country's economy on raw material cycles.

From these standpoints, we believe that the fiscal policy of Poland can be an excellent example for the government of Ukraine, particularly in terms of establishing fiscal discipline, converting public debt into economic development, establishing a system of tax incentives aimed at stimulating economic growth. In our viewpoint, the fundamental goal of fiscal policy of economic development should be stimulation of the development of the processing industry with a high share of value-added, reducing current expenditures from the state budget, and increasing expenditures on economic infrastructure, which is the basis of long-term economic growth.

Due to the limited statistical data or their complete absence, it was impossible to assess the effectiveness of the tax authorities of Poland and Ukraine in the academic paper. It is not possible to assess the actual effect on economic development from tax benefits in both countries. Therefore, promising areas of scientific research in this area can be studies of the quality of fiscal decisions, forasmuch as the effectiveness of any policy (as the art of managing) depends on the decisions made by people who are currently in power. Furthermore, to get a complete picture of the level of fiscal policy in Poland and Ukraine, it is essential to study the level of efficiency of the tax authorities and take measures to unshadow the national economy.

\section{References}

Adam, C. S., \& Bevan, D. L. (2005). Fiscal Deficits and Growth in Developing Countries. Journal of Public Economics, 89(4), 571-597.

Ahuja, D., \& Pandit, D. (2020). Public Expenditure and Economic Growth: Evidence from the Developing Countries. FIIB Business Review, 9(3), 228-236. https://doi. org/ 10.1177/23197145209378901. 
Ardanaz, M., Cavallo, E., Izquierdo, A., \& Puig, J. (2021). Growth-Friendly Fiscal Rules? Safeguarding Public Investment from Budget Cuts Through Fiscal Rule Design. Journal of International Money and Finance, 111, 102319. https://oi.org/10.1016/ j.jimonfin.2020.102319.

Arjomand, M., Emami, K., \& Salimi, F. (2016). Growth and Productivity: The Role of Budget Deficit in the MENA Selected Countries. Procedia Economics and Finance, 36, 345-352. https://doi.org/10.1016/S2212-5671(16)30046-6.

Bah, M., \& Kpognon, K. (2020). Public Investment and Economic Growth in ECOWAS Countries: Does Governance Matter. African Journal of Science, Technology, Innovation and Development. In-press. https://doi.org/10.1080/20421 338.2020.1796051.

Barro, R. J. (1990). Government Spending in a Simple Model of Endogenous Growth. Journal of Political Economy, 98(5, Part 2), S103-S125.

Benos, N. (2009). Fiscal Policy and Economic growth: Empirical Evidence from EU Countries. MPRA Paper No. 19174.

Bergman, U. M., Hutchison, M. M., Jensen, S. E. H. (2016). Promoting Sustainable Public Finance in the Europaen Union: The Role of Fiscal Rules and Government Efficiency. European Journal of Political Economy, 44, 1-19. https://doi.org/10.1016/j. ejpoleco.2016.04.005.

Chen, C., Yao, S., Hu, P., \& Lin, Y. (2017). Optimal Government Investment and Public Debt in an Economic Growth Model. China Economic Review, 45, 257-278. https://doi.org/10.1016/j.chieco.2016.08.005.

David, M. A. (2017). Fiscal Policy Effectiveness in a Small Open Economy: Estimates of Tax and Spending Multipliers in Paraguay. IMF Working Paper.

Dey, S. R., \& Tareque, M. (2020). External Debt and Growth: Role of Stable Macroeconomic Policies. Journal of Economics, Finance, and Administrative Science, 25(50), 185-204. https://doi.org/10.1108/JEFAS-05-2019-0069.

Djulius, H. (2018). Foreign Direct Investment or External Debt and Domestic Saving: Which Has Greater Impacts on Growth. Etikonomi, 17(1), 37-44.

Działo, J. (2012). Fiscal Rules and Effective Fiscal Policy. Comparative Economic Research, 15(2), 65-78.

Esfahani, H. S., \& Ramírez, M. T. (2003). Institution, Infrastructure, and Economic Growth. Journal of Development Economics, 70(2), 443-477. https://doi.org/10.1016/ S0304-3878(02)00105-0.

Gomez-Gonzalez, J. E., Valencia, O. M., \& Sánchez, G. A. (2021). How Fiscal Policy Rules Can Reduce Sovereign Debt Default Risk. Emerging Markets Review, In press. https://doi.org/10.1016/j.ememar.2021.100839.

Grazhevska, N., \& Virchenko, A. (2014). Special Features of the Ukrainian Fiscal Policy Transmission Mechanism under Increasing Macroeconomic Instability. Procedia Economics and Finance, 16, 680-689. https://doi.org/10.1016/S2212-5671(14)00856-9. 
Hart, N. (2013). Macroeconomic Policy Formulation: Functional Finance versus Sound Finance. Global Business and Economics Review, 15(1), 36-48. https://doi.org/10.1504/ GBER.2013.050666.

Heylen, F., Hoebeeck, A., \& Buyse, T. (2013). Government Efficiency, Institutions, and the Effects of Fiscal Consolidation on Public Debt. European Journal of Political Economy, 31, 40-59. https://doi.org/10.1016/j.ejpoleco.2013.03.001.

Khan, H., Khan, U., Jiang, L. J., \& Khan, M. A. (2020). Impact of Infrastructure on Economic Growth in South Asia: Evidence from Pooled Mean Group Estimation. The Electricity Journal, 33(5), 106735. https://doi.org/10.1016/j.tej.2020.106735.

Kusumasari, D. (2020). External Debt of Indonesia: From Debt-Led Growth to GrowthLed Debt? Jurnal Ekonomi Pembangunan, 18(1), 21-30. https://doi.org/1029259/ jep.v18i1.10801.

Larch, M., Orseau, E., \& der Wielen, W. (2021). Do EU Fiscal Rules Support or Hinder Counter-Cyclical Fiscal Policy. Journal of International Money and Finance, 112, 102328. https://doi.org/10.1016/j.jimonfin.2020.102328.

Molocwa, G. A., Khamfula, Y., \& Cheteni, P. (2018). Budget Deficits, Investment and Economic Growth: A Panel Cointegration Approach. Investment Management and Financial Innovations, 15(3) 182-189. https://doi.org/10.21511/imfi.15(3).2018.15.

Montes, G. C., Bastos, J. C. A., \& Olivieira, A. J. (2019). Fiscal Transparency, Government Effectiveness and Government Spending Efficiency: Some International Evidence Based on Panel Data Approach. Economic Modelling, 79, 211-225. https:// doi.org/10.1016/j.econmod.2018.10.013.

Niggle, C. J. (2010). Reinventing Functional Finance: Transformational Growth and Full Employment. Review of Political Economy, 22(1), 165-168. https://doi.org/10.1080/ 09538250903090416.

Nguyen, C. T., \& Trinh, L. T. (2018). The Impact of Public Investment on Private Investment and Economic Growth: Evidence from Vietnam. Journal of Asian Business and Economic Studies, 25(1), 15-32. https://doi.org/10.1108/JABES-04-2018-0003.

Nizioł, K. (2018). Fiscal Rules in Poland and Their Effectiveness (Chosen Legal and Economic Issues). Financial Law Review, 10(2), 45-59.

Owsiak, S. (2016). System Podatkowy Polski w Okresie Transformacji-próba Oceny. Annales Universitatis Mariae Curie-Sktodowska, Sectio H Oeconomia, 50(1), 15-27.

Palei, T. (2015). Assessing the Impact of Infrastructure on Economic Growth and Global Competitiveness. Procedia Economics and Finance, 23, 168-175. https:// doi.org/10.1016/S2212-5671(15)00322-6.

Reinhart, C., \& Rogoff, K. (2010). Growth in a Time of Debt. NBER Working Paper 15639.

Renshaw, P. (1999). Was There a Keynesian Economy in the USA between 1933 and 1945?. Journal of Contemporary History, 34(3), 337-364.

Shevchuk, V., \& Kopych, R. (2018). Fiscal Policy Effects in Ukraine. Argumenta Oeconomica Cracoviensia, (18), 33-50. 
Stawska, J. (2017). Imbalance of The Public Finance in The Context of Keynesian and Non-Keynesian Effects of Fiscal Policy Limitation. International Journal of Management Science and Business Administration, 3(3), 27-32.

Stoilova, D., \& Patonov, N. (2020). Fiscal Policy and Growth in a Small Emerging Economy: The Case of Bulgaria. Society and Economy, 42(4), 386-402. https://doi. org/10.1556204.2020.00015.

Teles, V. K., \& Mussolini, C. C. (2014). Public Debt and the Limits of Fiscal Policy to Increase Economic Growth. European Economic Review, 66, 1-15. https://doi. org/10.1016/j.eurocorev.2013.11.003.

Tung, L. T. (2018). The Effect of Fiscal Deficit on Economic Growth in an Emerging Economy: Evidence from Vietnam. Journal of International Studies, 11(3), 191-203. https://doi.org/10.14254/2071-8330.2018/11-3/16.

Wibowo, M. G. (2017). Public Debt and Economic Growth in The Southeast Asia Counries. Signifikan: Jurnal Ilmu Ekonomi, 6(1), 177-188. 